\title{
Effect of low temperatures on the infectivity of Toxocara cati larvae parasitized in mouse tissues
}

\author{
K. TAIRA ${ }^{1 *}$, V. ŠNÁBEL ${ }^{2}$, N. OKADA ${ }^{1}$, Y. SAITOH ${ }^{1}$ \\ ${ }^{1}$ Laboratory of Parasitology, Department of Veterinary Medicine, Azabu University, 1-17-71 Fuchinobe, Sagamihara \\ Chuo-ku, Kanagawa 252-5201, Japan, E-mail: taira@azabu-u.ac.jp; ${ }^{2}$ Institute of Parasitology, Slovak Academy \\ of Sciences, Hlinkova 3, 04001 Košice, Slovakia
}

\begin{abstract}
Summary
The infectivity of Toxocara cati larvae in mouse tissues, following storage at $4{ }^{\circ} \mathrm{C}$ and $-25^{\circ} \mathrm{C}$, was measured using a bioassay in mice. Tissues of donor mice infected with 30day-old $T$. cati larvae were stored at $4{ }^{\circ} \mathrm{C}$ for 7 and 14 days, and at $-25{ }^{\circ} \mathrm{C}$ for 24 hours, then tissue larvae were inoculated into recipient mice ( $n=6 /$ group). After 15 days, larval burden in recipient mice was assessed by digestion. In the control group, a mean of $42.0 \%$ of the inoculated larvae were established in mice. Storage of tissues at $4{ }^{\circ} \mathrm{C}$ for 7 and 14 days did not affect larval infectivity; means of $43.5 \%$ and $37.4 \%$ of inoculated larvae, respectively, were established in mice. Larvae exposed to $-25{ }^{\circ} \mathrm{C}$ for 24 hours did not establish in mice, except for one larva recovered from a single mouse. These results may support the potential of tissue larvae in livestock animals as a causative agent of human toxocarosis.
\end{abstract}

Keywords: Toxocara cati; tissue larvae; cold tolerance; zoonosis

\section{Introduction}

The common roundworm of cats, Toxocara cati, is an etiological agent of human toxocarosis with serious medical importance (Fisher, 2003; Akao \& Ohta, 2007; Lee et $a l ., 2010)$. In addition to direct infection from eggs shed in the environment, cultural dietary preferences for raw or undercooked meat dishes may be associated with a risk of infection (Taira et al., 2004). Accumulating evidence links human toxocarosis to the consumption of raw or undercooked meat (Mitsugi et al., 1988; Nishikata et al., 1991; Yoshikawa et al., 2010; Okulewicz et al., 2012), and an experimental study demonstrated that $T$. cati larvae persist and retain high infectivity in the muscles of chickens (Taira et al., 2011).

As refrigeration or freezing of meat products are common means of preservation throughout the consumer chain, an assessment of the risk associated with the consumption of $T$. cati-infected meat should include controlled experimental studies on the survival of larvae at low temperatures. It has been demonstrated that $T$. cati larvae in chicken muscle tissue retained infective even after 14 days of refrigeration at $4{ }^{\circ} \mathrm{C}$, but also that deep freezing appeared to be an effective inactivation measure (Taira et al., 2012).

Laboratory mice are easier to handle for experiments than chickens, particularly for studies to assess the infectivity of tissue larvae. In the present study, the infectivity of $T$. cati larvae in mouse tissues after storage at $4{ }^{\circ} \mathrm{C}$ and $-25^{\circ} \mathrm{C}$ was therefore investigated, and the results were compared with those obtained from previous study undertaken in the chicken model (Taira et al., 2012).

\section{Material and methods}

\section{Parasite isolates}

Eggs of $T$. cati were obtained from an experimentally infected cat. Fecal eggs were isolated, embryonated and stored in $1 \%$ formalin at $25{ }^{\circ} \mathrm{C}$ for approx. 3 months (Taira et al., 2012). The eggs were washed twice with tap water prior to inoculation to remove the formalin.

Donor mice: infection and necropsy

Twenty four 5-week-old male mice (outbred ICR strain) were inoculated orally with about 5500 embryonated $T$. cati eggs in $0.1 \mathrm{ml}$ of an egg suspension. Food and water were administered ad libitum. All mice were euthanized and necropsied at 30 days post-infection.

Whole carcasses, excluding the skin, tips of limbs, tails, muzzles, stomach and intestines, were cut into pieces measuring less than approx. $5 \mathrm{~mm}^{3}$ with a commercial food processor. 


\section{Preservation of the mouse tissues}

The entire preparation of thoroughly mixed mouse tissue was divided into 12 portions of $50 \mathrm{~g}$ each, and these were placed in plastic bags. All portions of minced tissues in the plastic bags were flattened to about $2 \mathrm{~cm}$ in thickness. Three control bags were not stored, and the larval burden in these bags was assessed at the day of necropsy by $\mathrm{HCl}-$ pepsin digestion. Three sets of 3 bags were stored at $4{ }^{\circ} \mathrm{C}$ for 7 days, at $4{ }^{\circ} \mathrm{C}$ for 14 days, and at $-25^{\circ} \mathrm{C}$ for 24 hours, respectively. After storage, larvae in tissues were immediately released by digestion as described below.

\section{Recipient mice: infection and necropsy}

Twenty four 5-week-old male mice (outbred ICR strain) were used as recipient mice. Four groups of 6 mice were each inoculated with around 100 larvae per mouse in approx. $0.5 \mathrm{ml}$ saline, per os by stomach tubing. Inoculation was conducted within 1 hour after digestion to release the larvae. Fifteen days after inoculation, mice were euthanized. The whole carcass of each mouse, excluding the skin, tip of limbs, tail, muzzle, stomach, and intestines, was minced into pieces measuring approx. $5 \mathrm{~mm}^{3}$ with a commercial food processor, and digested for larval recovery. The food processor was disinfected and washed with boiling water between the processing of each carcass.

All animals used in the study were treated in accordance with the guidelines for animal experimentation of Azabu University, and the relevant ethical guidelines of the Japanese Ministry of Education, Culture, Sports, Science and Technology.

Table 1. Infectivity of Toxocara cati larvae from mouse tissue after storage at $4{ }^{\circ} \mathrm{C}$ or $-25^{\circ} \mathrm{C}$

\begin{tabular}{|c|c|c|c|c|c|}
\hline Donor mouse tissues $^{\mathrm{a}}$ & Recipi & mice & & & \\
\hline $\begin{array}{c}\text { Preservation } \\
\text { temperature and } \\
\text { duration }\end{array}$ & ID & $\begin{array}{l}\text { Mean number of larvae } \\
\text { inoculated }( \pm 95 \% \text { CI })\end{array}$ & $\begin{array}{c}\text { Necropsy days after } \\
\text { inoculation }\end{array}$ & $\begin{array}{l}\text { Number } \\
\text { of larvae } \\
\text { recovered }\end{array}$ & Recovery \% \\
\hline & & $\mathrm{A}$ & & B & $\mathrm{B} / \mathrm{Ax} 100$ \\
\hline & 1 & & & 33 & $35.9 \%$ \\
\hline & 2 & & & 28 & $30.4 \%$ \\
\hline 0 days & 3 & 92 & 15 & 29 & $31.5 \%$ \\
\hline 0 days & 4 & $( \pm 9.4)$ & 10 & 88 & $95.7 \%$ \\
\hline & 5 & & & 37 & $40.2 \%$ \\
\hline & 6 & & & 17 & $18.5 \%$ \\
\hline & Mean & & & 38.7 & $42.0 \%$ \\
\hline & 7 & & & 29 & $29.6 \%$ \\
\hline & 8 & & & 51 & $52.0 \%$ \\
\hline $4{ }^{\circ} \mathrm{C} 7 \mathrm{dou}$ & 9 & 98 & 15 & 48 & $49.0 \%$ \\
\hline 4 C, / days & 10 & $( \pm 8.2)$ & 15 & 32 & $32.7 \%$ \\
\hline & 11 & & & 50 & $51.0 \%$ \\
\hline & 12 & & & 46 & $46.9 \%$ \\
\hline & Mean & & & 42.7 & $43.5 \%$ \\
\hline & 13 & & & 35 & $35.4 \%$ \\
\hline & 14 & & & 41 & $41.4 \%$ \\
\hline $4^{\circ} \mathrm{C} 11^{-19 u s}$ & 15 & 99 & 15 & 41 & $41.4 \%$ \\
\hline 4 C, 14 days & 16 & $( \pm 12.7)$ & 12 & 44 & $44.4 \%$ \\
\hline & 17 & & & 10 & $10.1 \%$ \\
\hline & 18 & & & 51 & $51.5 \%$ \\
\hline & Mean & & & 37.0 & $37.4 \%$ \\
\hline & 19 & & & 0 & $0.0 \%$ \\
\hline & 20 & & & 1 & $0.9 \%$ \\
\hline$-25^{\circ} \mathrm{C} 1 \mathrm{dav}$ & 21 & 115 & 15 & 0 & $0.0 \%$ \\
\hline-20 C, I day & 22 & $( \pm 13.4)$ & 10 & 0 & $0.0 \%$ \\
\hline & 23 & & & 0 & $0.0 \%$ \\
\hline & 24 & & & 0 & $0.0 \%$ \\
\hline & Mean & & & 0.2 & $0 \%$ \\
\hline
\end{tabular}

\footnotetext{
${ }^{\mathrm{a}}$ Whole carcass, excluding the skin, tips of limbs, the tail, muzzle, stomach and intestines, of 24 mice inoculated with about 5500 embryonated Toxocara cati eggs, and necropsied 30 days after inoculation. The tissues were cut into pieces measuring less than approx. $5 \mathrm{~mm} 3$, and $50 \mathrm{~g}$ patties
} of tissue, each about $2 \mathrm{~cm}$-thick, were preserved at temperatures and for durations, as described. 


\section{Digestion and larval counts}

The muscle digestion was conducted using the method of Taira et al. (2012). Briefly, the carcass of each mouse was digested in an $\mathrm{HCl}$-pepsin solution for 2 hours. The ratio between tissue $(\mathrm{g})$ and fluid $(\mathrm{ml})$ was approximately 1:10. The digestion solution was sedimented for 1 hour and washed three times in $40{ }^{\circ} \mathrm{C}$ saline. Immediately after the final sedimentation, the recovered larvae were counted under a stereomicroscope.

\section{Results}

No clinical signs of infection or changes in behavior were observed in any mice during the experiment. The infectivity of $T$. cati larvae in mouse tissues stored at $4{ }^{\circ} \mathrm{C}$ or $25^{\circ} \mathrm{C}$ are presented in Table 1 . A mean of $42.0 \%( \pm 27.26$ $\mathrm{SD})$ of the larvae obtained from donor mouse tissues at necropsy (controls) were recovered from the recipient mice. When administered tissues had been previously stored at $4{ }^{\circ} \mathrm{C}$ for 7 days, a mean of $43.5 \%$ ( $\left.\pm 9.82 \mathrm{SD}\right)$ of the inoculated larvae were established in recipient mice after 15 days. When tissues were stored at $4{ }^{\circ} \mathrm{C}$ for 14 days prior to inoculation of recipient mice, a mean of $37.4 \%$ $( \pm 14.35 \mathrm{SD})$ of the inoculated larvae were recovered from recipient mice after 15 days. There were no statistically significant differences in recovery percentages of larvae among 0,7 and 14 days of storages at $4{ }^{\circ} \mathrm{C}(\mathrm{p}>0.05$, a one-way ANOVA with two-tailed test).

When the tissues containing larvae were stored at $-25{ }^{\circ} \mathrm{C}$ for 24 hours, no larvae were recovered from 5 out of 6 recipient mice, with one larva being recovered from the remaining mouse at necropsy after 15 days.

\section{Discussion}

The present study provides data on the infectivity of $T$. cati larvae in mouse tissue, after either refrigeration or deep freezing of the meat, to compare with those data from larvae in chicken meat (Taira et al., 2012). The mouse bioassay employed in the present study substantiates that $T$. cati larvae retain high infectivity in mouse tissue stored at $4{ }^{\circ} \mathrm{C}$ for up to two weeks.

Taira et al. (2012) demonstrated that a mean of $47.1 \%$ of larvae in fresh chicken meat were established in recipient mice, whereas a mean of only $24.1 \%$ of the larvae present in chicken meat stored at $4{ }^{\circ} \mathrm{C}$ for 14 days were established. The authors assumed that this reduction in infectivity was a consequence of the decay of the meat, and the duration of exposure of the larvae to low temperature was not primarily impacted. The results of the present study support this assumption; the percent recovery of larvae in mouse tissue stored at $4{ }^{\circ} \mathrm{C}$ for 14 days $(37.4 \%)$ was not significantly reduced and was similar to that of the nonstored larvae used as control $(42.0 \%)$.

Deep freezing is regarded as an effective measure to inactivate $T$. cati larvae in mouse tissues, although one larva was herein recovered from a recipient mouse. Taira et al. (2012) reported that none of the larvae recovered after freezing of chicken meat at $-25^{\circ} \mathrm{C}$ were able to establish in mice. The authors observed a few motile but non-infective larvae released from meat frozen for 12 hours. Given that one larva was found in a recipient mouse inoculated with tissue stored at $-25{ }^{\circ} \mathrm{C}$ for 24 hours, further studies are required to determine the thermal dead point of $T$. cati larvae to derive the food safety implications.

In conclusion, the present report demonstrated that $T$. cati larvae in mouse tissues remained infective after 14 days of refrigeration at $4{ }^{\circ} \mathrm{C}$, and that deep freezing dramatically reduced the larval infectivity. Given that survival of the larvae in mouse tissues stored at $4{ }^{\circ} \mathrm{C}$ was higher than survival of the larvae in chicken tissues subjected to the same treatment and tested in the same way (Taira et al., 2012), screening of larvae in mouse tissue may be a useful model for an assessment of risk associated with the consumption of $T$. cati-infected meat.

\section{Acknowledgements}

This study was partially supported by a research grant (Young Scientist Research Training Award 2012) funded by the Azabu University Research Service Division.

\section{References}

Akao, N., Ohta, N. (2007): Toxocariasis in Japan. Parasitol. Int., 56: 87 - 93. DOI: 10.1016/j.parint.2007.01.009 FISHER, M. (2003) Toxocara cati: An underestimated zoonotic agent. Trends Parasitol., 19: 167 - 170. DOI: 10.1016/S1471-4922(03)00027-8

LeE, A. C., Schantz, P. M., Kazacos, K. R., Montgomery, S. P., Bowman, D. D. (2010): Epidemiologic and zoonotic aspects of ascarid infections in dogs and cats. Trends Parasitol., 26: 155 - 161. DOI: 10.1016/j.pt.2010.01.002

Mitsugi, K., Umei ,T., InOue, T., Sumida, I., HanadA, M. (1988): Visceral larva migrans by Toxocara cati with multiple nodules in liver. J. Nihon Naika Gakkai, 77: 1742 1743

Nishikata, H., Hirata, Y., Shimamura, R., Dohmen, K., Kudo, J., Ishibashi, H., OnIZUKA, H., OdA, M. (1991): A case of visceral larva migrans by Toxocara cati infection with multiple liver granuloma. Nihon Shokakibyo Gakkai Zasshi, 88: 2697 - 2702

Okulewicz, A., Perec-Matysiak, A., Buńkowska, K., Hildebrand, J. (2012): Toxocara canis, Toxocara cati and Toxascaris leonina in wild and domestic carnivores. Helminthologia, 49: 3 - 10, DOI: 10.2478/s11687-012-0001-6 Taira, K., SAeed, I., Permin, A., Kapel, C. M. (2004): Zoonotic risk of Toxocara canis infection through consumption of pig or poultry viscera. Vet. Parasitol., 121: 115 - 124. DOI: 10.1016/j.vetpar.2004.01.018

TAIRA, K., SAITOH, Y., KAPEL, C. M. (2011): Toxocara cati larvae persist and retain high infectivity in muscles of experimentally infected chickens. Vet. Parasitol., 180: 287 - 291. DOI: 10.1016/j.vetpar.2011.03.020

TAIra, K., SAitoh, Y., OKadA, N., Sugiyama, H., KaPEL, 
C. M. (2012): Tolerance to low temperatures of Toxocara cati larvae in chicken muscle tissue. Vet. Parasitol., 189: 383 - 386. DOI: 10.1016/j.vetpar.2012.04.037

Yoshikawa, M,. Koyama, N., Hontsu, S., Yamamoto,

RECEIVED FEBRUARY 5, 2013
Y., Ogawa, S., NaKamura, T., Mizuno, Y., Miura, S., MiKASA, K., KimURA, H. (2010): Clinical analysis of eight patients with pulmonary toxocariasis. J. Jpn. Resp. Soc., 48: $351-356$

ACCEPTED MARCH 15, 2013 